\title{
SEMANTIC ROLES IN JOKO WIDODO RE-ELECTED AS PRESIDENT OF BBC ONLINE NEWS
}

\author{
Maria Devi Sidabutar ${ }^{1}$ \\ Universitas Putera Batam (UPB), Indonesia \\ Zakrimal $^{2}$ \\ Universitas Putera Batam (UPB), Indonesia \\ pb161210097@upbatam.ac.id ${ }^{1}$ \\ Submit, 04-07-2020 Accepted, 20-07-2020 Publish, 24-07-2020
}

\begin{abstract}
This research focused in analyzing the types and the dominant of Semantic Roles that found in Joko Widodo re-elected as President in BBC Online News (2019). The research design of this study is descriptive qualitative. This research used Riemer (2010) theory. The data source of this research was "Joko Widodo reelected as President" in BBC Online News which was taken from the internet. The method in collecting the data of this research was observation with nonparticipatory technique by using the transcript. The conclusion was the eight types of semantic roles can be found of Joko Widodo re-elected as President in BBC Online. These data had been collected, the researcher found 10 data that produce 24 results of semantics roles which were involved into eight (8) types, such as; agent (3), patient (2), theme (5), location (2), experiencer (4), instruments (3), goal (2), and source (3) as the results. Also, the dominant types of the semantic roles that frequently appeared was theme and the least was patient, location, and goal.
\end{abstract}

Keywords : Semantic, News, Types of Semantic Roles.

\section{INTRODUCTION}

As the modern era, Indonesia politics has been opened for political actors to compete and retain power. Indonesia is included the country that almost its people wants to compete in the arena of political to reach the power and become a leader in the government such as be a president, mayor, regent, constitutional court, and others. Fierce the competition to be a leader in the political world, there are so many things that can be done to bring down the rival such as looking for flaws and failures. The things make the candidates who will be running less and less. In finding the flaws and failures of someone or rival, it will be easy in this era now. There are so many tools that can be used. 
In this era, the things to bring down the rival will be easy with making the interesting news even though the news is hoax. The things are all done to get a seat in government. The things can be done with using many electronics media such as television, online news, newspaper, magazines, and others that will be sending or writing news reporters trying to get the interesting news for reading by people. Usually, the news will be written by the journalists with the interesting title to influence the reader in the news. The things also will make the increasing rating for the journalists in the field of electronics media.

There are so many media are trying to cover the political news in Indonesia which is currently determining a presidential election. The $\mathrm{BBC}$ online news also is interesting to cover the news about the political news in Indonesia because of the presidential candidates are competing to be the leader. BBC (British Broadcasting Corporation is the largest online news media in the world and $\mathrm{BBC}$ also has the branch in Indonesia. The center of the BBC online office is in London, England, and also has more than twenty-three thousands people. This online news conveys all the news clearly and using the English language in variation words, and BBC also get so many awards.

Even though, BBC uses the English in various words, it also can make misinterpret meaning when the readers read the news or the listeners watch and listen to the content of the news. Because of that, it is needed the model of language that help the readers to understand how the text of the news works to interpret the meaning. The function of semantic roles can do this and describe language in actual and focus on texts and the contexts of culture or situation. So, the researcher must analyze the role of a word in the sentences. Semantic roles have eight types such as agent, patient, theme, location, experiencer, instruments, goal, and source. These types make the researcher grouping the words in the sentences into the eight types of the semantic roles.

Marlina (2012) which found that nine kinds of thematic role such as agent, patient, location, beneficiary, experiencer, theme, source, goal and instrument are available in narrative texts and the role theme was frequently employed. there are six categories of the types of passive construction, such as : infinitive passive, get passive, be passive, impersonal passive, imperative passive, and causative passive. Humolungo, (2013) that analyzed the passive sentences by semantic role analysis. Hussain \& Sajid (2015) which found the roles of semantics in classifying the natural language predicates into a closed set of participant types in arguments and subfield of linguistics can be used in EFL classroom for better teaching learning process.

Next researcher in its research was Suryasa (2016) which had the result in showing the semantic has an important role involving to be understood by the reader with applied a figurative language that dominates the readers to know more 
about the story was. Those figurative language were metaphor, personification, hyperbole, simile, and synecdoche, then the most found was metaphor. Maharsi (2016) which showed results the position of noun phrase's determines its thematic role and the relevance between deep syntactic structure and the assignment of thematic roles for every noun phrase in the sentence. Another researcher was Agung (2016) analyzed the denotative meaning in Kidung Doa song which using the three lyrics as the data. Maisarah (2016) which analyzed the pronouns in relation to the placement of verbs in a Mah Meri sentential construction.

After that, the other researcher Simanjuntak (2019) in its research concluded an action verbs has actor roles as an agent, effector, locative, theme, and as the patient. Ismail (2019) the result showed the direct object that sometimes cannot be represented by inanimate in particular construction and prepositional phrases are optionally profiled in some cases. Then the last profiling and not profiling the roles of participants may have something to do with what that called semantic restriction. Then, Sutedi (2020) which used as reference material for Japanese lecturers in teaching of Japanese case particles then the differences among the particles will be clearer and more easily understood by Japanese language of learners in Indonesia.

Based on the previous researches and comparing with this research phenomenon, this research of semantic roles can be found in the world of education and society with the application as the fact is a news either in print or online. Then, the sentences and prepositions that had the basics of semantic roles in its also can be found in drama script, dialogue, especially in a news. Because of that, the researcher got an interested reason further to better learn and understand about using semantic roles or tasks in sentences and prepositions by including understanding and some examples.

\section{LITERATURE REVIEW}

\section{Semantics}

Semantics is one of the important branches of linguistics, it related with interpretation and meaning of the words, sentence structure, and symbols. It related with the reading comprehension of the readers, in how they understand others and their interpretations. Ningrat, et.al (2019) stated in addition, semantics constructs a relation between adjoining words and clarifies the sense of a sentence, whether the meanings of words are literal or figurative. The purpose of semantics is to propose exact meanings of words and phrases, and remove confusion, which might lead the readers to believe a word has many possible meanings.

It makes a relationship between a word and the sentence through their meanings. Besides, semantics enable the readers to explore a sense of the meaning 
because, if we remove or change the place of a single word from the sentence, it will change the entire meaning, or else the sentence will become anomalous. Hence, the sense relation inside a sentence is very important, as a single word does not carry any sense or meaning.

\section{Semantic Roles}

Wrihatnala (2016) stated semantic roles attempt to capture similarities and differences in verb meaning that are reflected in argument expression, with emergent generalizations that will contribute to the mapping from semantics to syntax. Semantic roles also known as thematic relations, theta roles, participants roles, and deep cases are labels for certain recurring predicate-argument relations. Semantic roles refers to the way in which the referent of the noun phrase contributes to the state, action or situation described by the sentence. There are eight of semantic roles such as agent, patient, theme, location, experiencer, instruments, goal and source Made Puspani (2016).

\section{Agent}

The role of an argument that by its action affects some other entity.

Ex : Sinta dropped the glass.

From the sentence, it can be known that Sinta is doing an action which causes the glass is broken.

\section{Patient}

The role of an argument that entity undergoing the effect of some action.

Ex : The refrigerator froze the water.

From the sentence, the refrigerator gave the effect for the water become freezing or being an ice.

\section{Theme}

The argument that undergoes an action.

Ex : Sandi lost the key.

From the sentence, the key was looking by Sandi and he did not find it.

\section{Location}

An argument the place where the action was happened.

Ex : The match football was held in University of Putera Batam.

From the sentence, it is known that University of Putera Batam was as the place for the match football was held. 


\section{Experiencer}

An argument that someone feels something.

Ex : Aunty heard that the baby was crying.

This sentence shows that Aunty heard the crying of baby.

\section{Instruments}

Argument that the means by which an action performed.

Ex : Suzy is eating the fried noodle with her hands.

This sentence shows that the fried noodle is eating by Suzy using her two of her hands

\section{Goal}

An argument that place from which an action is directed.

Ex : Throw this rubbish into the rubbish bin.

This sentence shows that the rubbish bin is the place of the rubbish must be.

Source

A role of argument that the place from which an action originates.

Ex : Maria comes from Medan.

This sentence shows that the source or the village of Maria comes from.

\section{RESEARCH METHOD}

This research used the descriptive qualitative research method which was result of the research. For collecting the data contains the semantic roles in Joko Widodo re-elected as President, the researcher used observation method with nonparticipatory technique that applyed by Sudaryanto. This research is describing an analysis of semantic roles Joko Widodo re-elected as President. The researcher determined the types of semantic roles and the dominant types of semantic roles that used in script as the data. The findings of the research were finally analyzed by the researcher.

\section{FINDINGS}

This research analyzed and classified the types of semantic roles that found in Joko Widodo re-elected as President of BBC Online News (2019). Here are ten (10) data which involving the eight (8) types of semantic roles in its.

\section{Data 1}

Joko Widodo has been re-elected as Indonesia's president after last month's vote, beating former general Prabowo Subianto. 
Based on the statement, there can be seen two types of semantic roles. Two of them are experiencer and theme. Here, Jokowi is an experiencer role who re-elected as the President of Indonesia. Mr. Widodo re-elected because getting the highest poll as the result, also his hard work in leading Indonesia and for advancing the country of Indonesia. Indonesia's president as the theme, because Mr. Widodo has won the voting.

\section{Data 2}

Around 32,000 security personnel were deployed across the capital Jakarta, AFP news agency reports.

There are also three types of semantic roles, patient, location, and agent. The 32,000 security personnel as the patient because taking care the result of voting in amid fears of unrest. The capital Jakarta is the location because the result of the voting will be announced there. Then, AFP news agency is the agent in reporting the condition of the result of voting that will be held.

\section{Data 3}

Mr. Prabowo rejected the result and said he would pursue "legal avenues", but urged his supporters to stay calm.

On the statement, there are two types of semantic roles are patient and goal. Mr. Prabowo is the agent who rejected the result of voting on himself. Legal avenues is the goal that Mr. Prabowo chooses as the weapon to re-process the result of voting on himself that cause Mr. Prabowo loses in the voting.

\section{Data 4}

Ahead of the final tally he had alleged "widespread cheating" and warned of potential street protests.

In 2014 Mr. Prabowo challenged an election defeat by Mr. Widodo in Indonesia's constitutional court, but lost.It can be found three types of semantic roles which are theme, agent, and location. Widespread cheating and warned of potential street protests as the theme which is Mr. Prabowo alleged and will be done because Mr. Prabowo cannot accept his defeat. Then, Mr. Prabowo as the agent that cannot accept his defeat in the voting. Indonesia's constitutional court is the location that the place for the legal avenues will be held that taken by Mr. Prabowo. 


\section{Data 5}

Mr. Widodo won 55.5\% of the vote to Mr. Prabowo's $44.5 \%$, the election commission said.

There are four types of semantic roles, they are experiencer, instrument, theme, and agent. Mr. Widodo is the experiencer that won the highest result in Indonesian presidential re-election. The vote as the instrument which is used as the valid poll in choosing the president. The poll $55.5 \%$ of vote which is the result of voting that the winner or Mr. Widodo got in Indonesian president re-election and $44.5 \%$ of vote which the voting that Mr. Prabowo got are as the theme. Mr. Prabowo is as the experiencer not as the patient because Mr. Prabowo got the lower poll in the result of voting. The election commission as the agent that saying the valid result of voting.

\section{Data 6}

Mr. Widodo, himself a religious moderat.

Here, there is only one type of semantic roles which is as instrument. Himself a religious moderate become as the instrument because Mr. Widodo is already known by people with the character that Mr. Widodo has.

\section{Data 7}

Jakarta's Chinese-Christian governor Basuki Tjahaja Purnama - known as Ahok - was accused by hardliners of blasphemy against Islam.

Here are three types of semantic roles which are the theme, source, and experiencer. Jakarta's Chinese-Christian governor as the theme that Mr. Basuki Purnama is the governor from chinese ethnic that ever leading Jakarta. ChineseChristian as the source because that shows the identity of Mr. Basuki Purnama or Ahok from christian and chinese ethnic. Mr. Basuki Purnama is as the experiencer who the governor of Jakarta that has been accused by hardliners of blasphemy against Islam.

\section{Data 8}

Joko Widodo has been president since 2014 when he also beat Mr Prabowo in a hotly-contested vote.

Here, Mr. Widodo is as the experiencer who ever as the president before and still re-elected as the President to advance Indonesia again. 


\section{Data 9}

The 57-year old comes from humble beginnings and has focused his campaigns very much around his image as a "man of the people".

Based on the statement, there are two types of semantic roles, those are source and instrument. Humble beginnings is the source that Mr. Widodo comes from the humble family and down-to-earth of character. His image as a man of the people became as the instrument because Mr. Widodo is already known by people with the character that Mr. Widodo has, it also became the style of leading Indonesia.

\section{Data 10 :}

He first came to international prominence by becoming governor of Jakarta in 2012.

From the statement, it can be found three types of semantic roles, those are source, theme, and goal. $\mathrm{He}$ is as the experiencer which refers to Mr. Joko Widodo that starting to be famous to International since Mr. Widodo became the governor of Jakarta. Mr. Widodo is a role model for Indonesian, because he is known as a wise and clever leader in solving existing problems. He always and still has the well record as long as he does his job as a leader, both when he was still a governor until the president again. The theme is governor of Jakarta that he was ever as governor during leading Jakarta before becoming president now.

\section{DISCUSSION}

This research has some results that the researcher found from the analysis of data. There are all the types or the eight types that used in Joko Widodo reelected as President of BBC Online News. The theory was applied by Riemer (2010). The using in types of semantic roles had its understanding based on how to use it in the sentences. Theme is the dominant type that appeared in the news which found by the researcher.

Theme is the argument that undergoes an action. "Mr. Widodo won 55.5\% of the vote to Mr. Prabowo's 44.5\%, the election commission said." From this sentence above, make sure that " $55.5 \%$ and $44.5 \%$ " was the poll that the each of candidates got at the party and it means that is as a theme which is talking about the argument undergoes an action. The least dominant is patient, location, and goal. From this sentence "Mr. Prabowo rejected the result and said he would pursue "legal avenues", but urged his supporters to stay calm." This statement, there Legal avenues is the goal that Mr. Prabowo chooses as the weapon to reprocess the result of voting on himself that cause Mr. Prabowo loses in the voting. 
Semantic roles can be divided into two types, that is to say, macroroles and specific roles by Valin (1997). The macroroles are divided between actors and undergoers. Specific roles of agent, patient, theme, locative, and experiencer can be referred to as subordinate roles. Agent is the actor who perfoms an action and who controls and restrains the occurrence of an event. Then, the patient is the undergoer who receives the action directly from the agent. The semantic role is a role played by the predicate argument so that it is said to offer a semantic relationship between the arguments and the predicates.

According to Yule (2006) the theory for analyzing the types of semantic roles of its sentence that stated had the result of the data about the words that including in its sentence. That thing done to determine what word it was called of its sentence, such as the role by the noun phrase of "The boy kicked the ball". The boy as the entity that performs the action that called as an agent. Another role is taken by the ball as the entity that is involved in or affected by the action, which is called as the theme. The theme typically non-human, but can be human too. In fact, the same physical entity can be appear in two different semantic roles in a sentence.

Geert (2007) stated that the semantic role refers to the verbs performed by general participants. In controlling, influence, and shape the situation and actions that affect the undergoer was influence from the actors himself. On the other hand, the target undergoer is participant who is only affected by verb actions that are said to be unable to control, do not form or not affect the situation as the agent does.

\section{CONCLUSION}

There are eight types of semantic roles can be found in the news Joko Widodo re-elected as President in BBC Online. These data has been collected, the researcher found 10 data that produce 24 results of semantics roles which were involved into eight (8) types, such as; agent (3), patient (2), theme (5), location (2), experiencer (4), instruments (3), goal (2), and source (3) as the results. Also, the dominant types of the semantic roles that frequently appeared was theme and the least was patient, location, and goal as the conclusion.

\section{REFERENCES}

Agung, \& Satriyo, W.,W. (2016). A Semantic Analysis of Denotative Meaning in Kidung Doa Song by Sunan Kalijaga. Jurnal Ilmiah Bahasa dan Sastra, $3(48), 1-20$.

Geert, B. (2007). The Grammar of Words: an Introduction to Morphology. Oxford Textbooks in Linguistics. Oxford: Oxford University Press.

Humolungo, F. (2013). Analyzing Passive Sentences through Semantic Roles Analysis. Universitas Negeri Gorontalo. 
Hussain, S., \& Sajid, S. (2015). Semantics in EFL Classroom: a Brief Review. IOSR Journal Of Humanities And Social Science (IOSR-JHSS), 20(9), 3943. https://doi.org/10.9790/0837-20933943

Indonesia election: Joko Widodo re-elected as president. (2019). Retrieved from https://www.bbc.com/news/world-asia-48331879

Ismail, D. (2019). Profiling Properties of the Verbs Bring, Mails, Send, Rob, and Steal in the News of Washington Post and Pittsburg-gazette. JOEPALLT, $7(2), 1-10$.

Maharsi, E. (2016). Thematic Role Assignment in English Sentences : a Quick Glance an Interface between Syntax and Semantics. ELTICS : Journal of English Language Teaching and English Linguistics, 2(1), 15.

Maisarah, K. \& V. (2016). Semantic Analysis of Theta Roles of Verbs in the Mah Meri Language. Journal of English Education, 5(1), 49-70.

Marlina, R. (2012). The Analysis of Thematic Role in Narrative Texts of Senior High School Textbooks. English Review: Journal of English Education, $1(1), 80-88$.

Ningrat, A.,A.,A Ngr. Adriyanti, W., Kardana, I., N. (2019). Semantic Roles of the Verb "to See" in Javenese of Kertosono. 5(2), 122-129. https://doi.org/http://dx.doi.org/10.22225/jr.5.2.1139.122-129

Puspani, M., I., A. (2016). The Semantic Roles of the English Action Verbs. Jurnal Humanis, 16(2), 159-166.

Riemer, N. (2010). Introducing Semantics. United Kingdom: Cambridge University Press.

Simanjuntak, F. \& M. (2019). Semantic Roles of Verbs in Batak Toba Language. European Journal of Literature, Language and Linguistics Studies, 3(2), 1-15. https://doi.org/10.5281/zenodo.3334399

Suryasa, I., W. (2016). The Roles Played of Semantic Theory Found in Novel the Moon that Embracing the Sun Translation. International Journal of Linguistics, Literature and Culture, 2(1), 39-42.

Sutedi, D. (2020). The Semantic Roles of " kaku-joshi" in Japanese Textbooks. Indonesian Journal of Applied Linguistics, 5(3), 545-558.

Valin, V. \& L. (1997). Syntax: Structure, Meaning, and Function. Cambridge University Press.

Wrihatnala, I., M., B. (2016). Category of Complement and Semantic Role of Single Argument in Balinese Syntactic Constructions. 2(2), 384-393. https://doi.org/10.22225/jr.2.2.423.384-393. 